Wright State University

From the SelectedWorks of Rebecca Teed

2014

\title{
Increasing Teachers' Confidence and Pedagogical Content Knowledge Through a Workshop and Follow-Up Program on Climate Change
}

Rebecca Teed, Wright State University

Suzanne Franco, Wright State University 


\title{
INCREASING TEACHERS' CONFIDENCE AND PEDAGOGICAL CONTENT KNOWLEDGE THROUGH A WORKSHOP AND FOLLOW-UP PROGRAM ON CLIMATE CHANGE ${ }^{1}$
}

Rebecca Teed ${ }^{2}$ (rebecca.teed@wright.edu) \& Suzanne Franco ${ }^{3}$

\begin{abstract}
An Earth science professional-development program for in-service middle- and high school teachers increased participants' content knowledge about weather, climate, and climate change in addition to increasing their confidence in their assessment and teaching skills. The curriculum and funding gave them time, funding, and the help of content and pedagogic experts to build and test new lesson plans on these topics. During the summer workshop, the teachers participated in field trips, hands-on lab experiences, and cooperative inquiry projects. They studied weather and mechanisms that determine climate during the first week. The second week focused on geologic time and changes in the Earth system that drive climate changes on long timescales. The major topic for the third week was anthropogenic climate change. During the workshop, the teachers designed lesson plans for multi-day units on workshop topics.
\end{abstract}

The teachers took a content pre-test at the start of the summer workshop and a posttest at the end. Their average score increased from $38.1 \%$ to $75.6 \%$. The follow-up program included three meetings and two classroom visits by a veteran teacher during the subsequent school year. The participants taught their lesson plans and administered to their own students pre- and post-tests that they had designed. Their class scores showed normalized gains ranging from $16 \%$ to $88 \%$. Surveys taken at the beginning of the summer workshop and the end of the follow-up program indicated an average increase in their confidence of their ability to teach science and in their willingness to employ hands-on, cooperative, and inquiry learning techniques in their classrooms.

Key Words: climate literacy, Earth history, jigsaw, teacher workshop, assessment

\footnotetext{
${ }^{1}$ This is an Accepted Manuscript of an article published by Taylor \& Francis in the Journal of Geoscience Education on 2014, available online at http://www.tandfonline.com/10.5408/13039.1.

${ }^{2}$ Dept. of Earth \& Environmental Sciences ${ }^{1}, 260$ Brehm Laboratories, Wright State University, 3640 Colonel Glenn Highway, Dayton OH 45435

${ }^{3}$ Dept. of Educational Leadership, 455 Allyn Hall, Wright State University, 3640 Colonel Glenn Highway, Dayton OH 45435
}

R. Teed and S. Franco. 2014. Journal of Geoscience Education 62(4), 587-597. DOI: 10.5408/13-039.1 


\section{INTRODUCTION}

Eighteen in-service teachers (mostly middle- and high-school) completed the Wright State Institute for Teacher Quality (ITQ) Earth science summer workshop in 2011 on climate change over geologic time. Most finished a follow-up program during the 2011-2012 academic year. These experiences enhanced their content knowledge of climate change and Earth history and, in many cases, broadened their experience of inquiry learning. The Earth science workshop ran alongside a physical science and a life science workshop. Participants could only take part in one of the three workshops during any given year, but several of the teachers in the 2011 Earth science workshop had completed an ITQ life science workshop in previous years.

Instructor and evaluator salaries, the cost of the participants' textbooks and the classroom materials for their unit plans (up to \$425/participant), participant stipends (awarded at the end of the follow-up program), the costs for substitutes teachers for the three follow-up workshops, and other expenses were covered by a 2010 - Improving Teacher Quality grant from the Ohio Board of Regents (OBR). Participants received graduate credit from the Department of Earth and Environmental Sciences for the summer workshop component and from the Department of Teacher Education for the follow-up program. Wright State University waived the fees and tuition costs. The only costs to the teachers themselves were transportation to the workshop and most lunches.

Ohio had recently adopted new science content standards (Ohio Department of Education, 2011a, 2011b). All three ITQ workshops offered opportunities to deepen content knowledge of topics relevant to the standards and to develop lesson plans that addressed them. This paper describes the new curriculum developed for the Earth science workshop, the effects on the participants and on their students, and some of the challenges to involving participants from high-needs districts in an effective teacher workshop.

At a national level, the first recommendation in the report Rising above the Gathering Storm: Energizing and Employing America for a Brighter Economic Future (Committee on Prospering in the Global Economy of the 21st Century, 2007) is to enhance the content knowledge of K-12 science, mathematics, and engineering teachers. Not only could these teachers increase the number of American scientists and engineers (over time), but they also have the potential to increase the science literacy, technological skills, and mathematical ability of all young Americans. The committee specifically recommends funding summer institutes for K-12 teachers to develop greater science and math content knowledge with the goal of increasing student learning (A-2 Part 1 ) and funding competitive institutional grants for science and math master's degree programs (A-2 Part 2).

The few scientific studies of teacher professional development examined by Yoon et al. (2007) indicate that effective programs generally take time (more than 14 contact hours), include a follow-up program after the workshop, and are taught directly to the teachers by researchers, as opposed to indirect training using district personnel. The Summer Science and Math Institutes for Teacher Quality (ITQ) at Wright State University meet or exceed these recommendations. This program has been run at least 10 times at since 1998, with funding from the Ohio Board of Regents Improving Teacher Quality State Grants Program, and generally

R. Teed and S. Franco. 2014. Journal of Geoscience Education 62(4), 587-597. DOI: 10.5408/13-039.1 
consists of two or three workshops running simultaneously, with about 24 participants apiece (Basista and Matthews, 2002). The workshops are taught by mixed teams of college professors with doctoral degrees and highly-qualified, experienced K-12 teachers. The summer programs include at least 72 contact hours, rely on inquiry more than on didactic instruction, and focus on increasing participants' content knowledge and pedagogical content knowledge (PCK). They are assessed through pre- and post-tests of both the participants and the participants' students. These workshops offer continuing education credit and graduate credit towards a masters' degree.

Ohio had developed its own set of science content standards in 2003 (Ohio Department of Education, 2003), but these were replaced with a new set in 2011 . Ohio teachers needed to update their content knowledge and rebuild their curricula to implement the new state science standards. Many of the topics for Earth science at the middle- and high school levels are the same, but not all. The emphasis was shifted from topics to themes (called "strands") that connected life, Earth, and physical science at the middle-school levels. For example, in seventh grade, the theme is cycles of matter and energy exchange. Inquiry and technological literacy are no longer separate standards but are integrated within the others (Ohio Department of Education, 2011a). The new high school standards outline specific recommendations for courses in Advanced Sciences, including Physical Geology and Environmental Science (Ohio Department of Education, 2011b).

At the middle-school level, Ohio's science standards are divided into three areas: Earth and space science, life science, and physical science, so the ITQ workshops for 2011 were divided into the similar categories. The topic for the 2011 Earth science workshop was climate change over geologic and recent timescales. Climate change and geologic time are relevant to several of the Earth and space science and life science standards, but these topics are complex and controversial. Many teachers are not confident in their understanding of these topics and may avoid teaching them (Trend, 2001; Dahl et al., 2005; Wise, 2010), despite the pressure from the state and their administrations.

Climatology and Earth history are great vehicles for teaching about the nature of science (as described by McComas and Almazroa, 1998). In Ohio, as in many areas, students can collect fossils of marine organisms far from the modern ocean, and these provide empirical evidence for sea-level change. New evidence can overthrow established theories, so every theory is somewhat tentative, even if well-supported at the present time. For instance, careful analysis of glacial deposits in Europe and North America led scientists to infer that there had been four ice ages during the Pleistocene and that these could be correlated globally (e.g. Wright, 1914), but closer examination of those deposits (e.g. Richmond and Fullerton, 1986) and analysis of ${ }^{18} \mathrm{O}$ ratios in ocean cores indicate that there were many more than four ice ages, and correlation, even across a few hundred miles, is still difficult. Scientific knowledge is socially negotiated (McComas and Almazroa, 1998), often through debates, like the ones over the cause of the extinction of the dinosaurs (Glen, 1994).

R. Teed and S. Franco. 2014. Journal of Geoscience Education 62(4), 587-597. DOI: 10.5408/13-039.1 


\section{PARTICIPANT POPULATION}

The ITQ program was funded by a grant from the OBR; the original proposal targeted teachers from two local high-needs districts, Dayton City and Trotwood. Administrators from these two partner districts sent letters of support for the program to the OBR. Teachers from Dayton City Schools were allowed to register a month before teachers from other districts, and two of the district's curriculum specialists were given details about the program to use for recruiting. However only seven Dayton City teachers and one Trotwood teacher applied to participate in the Earth science ITQ workshop. Of those, two dropped out of the workshop after the first week, and two did not complete the follow up-program. Most of these teachers worked in schools rated "Academic Watch" in 2010-2011 (Table 1), meaning that their students have scored poorly on standardized tests for at least two consecutive years and that they are eligible for state sanctions.

Anyone with a bachelor's degree who taught school in Ohio was eligible to participate in the ITQ program. Of the twelve applicants from non-targeted districts, most taught in schools with an "Excellent" rating. One came from a private school (Table 1). The Earth science workshop began with twenty in-service teachers, fourteen female and six male. Fourteen taught grades K-8, including two special-education teachers, and six taught high-school science (Table 1). Data on participant race and age were not used to evaluate the project.

The ITQ summer workshop included two other workshops taught in nearby classrooms that followed the same format and used the same schedule: physical science and life science. The physical science workshop focused on energy and the life science one on evolution. The participants were similar in background to those in the Earth science workshop, and the classes suffered similar dropout rates. The participants in the Earth science workshop worked with those in the life science workshop on a couple of projects during week 2.

\section{PROGRAM CURRICULUM}

The first week of the summer workshop focused on the causes of weather and climate, the second on geologic time and past climate change, and the third week addressed recent anthropogenic climate change (Supplementary Material 1). The participants and instructors met in a science classroom at Wright State University four days a week for three weeks in June 2011 (the Earth science schedule is in Supplementary Material 2). The classroom had a computer connected to the Internet and a projector so that both the instructors and the students could give video or PowerPoint presentations. There were a total of three instructors for the Earth science workshop: two college professors with doctorates and a K-12 teacher with at least one master's degree.

\section{Week I: Climate Mechanism Jigsaw}

The first three of the essential principles of climate literacy recommended by the U.S. Global Change Research Program (2009) were addressed during the first week (Table 2). Five important topics for understanding climate were divided up among the participant groups. Each group of four was given a list of questions to address and instructed to develop and teach a lesson to their colleagues (See Supplementary Material 3 for scaffold). The topics were 1) 
seasons: Sunlight, latitude and tilt, 2) Oceans, 3) the Coriolis effect: Cyclones and hurricanes, 4) Convection cells: Hadley, Ferrell, and Polar, and 5) Biomes (Köppen zones): Vegetation \& climate. A sixth topic, water vapor and humidity, was covered by the instructor because there were only 20 participants. The groups were to address these questions in a lesson. They were assigned a set of guidelines (the CoRe form) for developing a pedagogical content knowledge (PCK) framework for their topic (Mulhall et al., 2003). The CoRe form has the teacher start by breaking a topic into big ideas and addressing a series of issues for each idea, such as why it is important, how student knowledge will affect their teaching of it, strategies for addressing students' confusion surrounding it, etc.

Some groups incorporated limited pre- and post-testing ( 3 or 4 questions) into their lessons. Most were demonstrations with a hands-on component, but one group gave a lecture. Each participant was provided with a copy of Project Earth Science: Meteorology (NSTA, 2005), which provided readings, suggested activities, and links for resources, but after a close review, all of the participants elected to research on the Internet on their own to find information and ideas. Some developed demonstrations by experimenting with material in the classroom, using trial and error to determine the best procedure.

The second part of the jigsaw gave participants an opportunity to apply their understanding of climate. The participants formed new groups, with all participants in the new groups coming from different topic-groups from the climate-mechanism lesson that they had just completed. They were given a map of tropical Pangea during the mid-Triassic (Fig. 1). The instructor had marked six sites marked on it. Each group was assigned a site and told: "Those crazy teachers in the life-science workshop next door have gotten ahold of a time machine that will take them 230 million years in the past. They want to go back and establish a base so they can study evolution of early mammals and dinosaurs in the Triassic. Examine the geography of your site and determine the probable climate, including temperature ranges, prevailing winds, and seasonal rainfall. Would it be a good place for a research base? What about potential geologic and weather hazards? Will this site be safe? Will there be drinking water? How can the researchers generate electricity? Describe the local ecosystems." The participants were told to determine the paleolatitude of their base and to apply the information from the first part of the jigsaw on convection cells, the ocean, etc., to work out the climate (worksheet in Supplementary Material 4). When the participants presented their site analyses, most went beyond the questions that they had been given. Several named their bases.

\section{Week 2: Trends through Time Jigsaw}

In the second week, the activities focused on the third and fourth essential principles of climate literacy (U.S. Global Change Research Program, 2009; Table 2). On Thursday afternoon of week 1, participants from the Earth science and life science workshops went on a field trip together to collect Ordovician fossils from Caesar's Creek State Park in Waynesville, Ohio. Both groups were looking at problems of change over long timescales. Caesar's Creek fossils were left by ancient marine organisms, including horn corals and many types of brachiopod, providing the participants with spectacular evidence of environmental and biological changes and introducing the concept of geologic time scales. Over the weekend, the Earth science

R. Teed and S. Franco. 2014. Journal of Geoscience Education 62(4), 587-597. DOI: 10.5408/13-039.1 
participants completed personal timeline worksheets (Teed and Wright, 2014) to give them a sense of the scale of geologic history. At the end of week 2, they visited another site, Oakes Quarry, where Silurian fossils from a different environment (particularly crinoids) had been preserved.

For the Prehistoric Zoo exercise, the Earth-science and life-science workshop participants were combined and divided into new groups, each with a pair of Earth scientists and a pair of life scientists. Each group was assigned a Phanerozoic time period (e.g. the Devonian). The life scientists were instructed to choose charismatic extinct megafauna for a zoo and to describe the ecological and evolutionary characteristics of their choices. The Earth scientists were tasked with planning the expedition back in time to do the collecting. They were told to study the paleogeography, paleoclimate, and predator populations. The instructors recommended the Paleomap Project (Scotese, 2003), Colorado Plateau Geosystems (Blakey, 2014), and the UC-Berkeley Museum of Paleontology (University of California, 2014) as particularly helpful resources, but the participants preferred to find most of their sources on their own. The Earth scientists would use their information to predict the hazards that time traveling life scientists would probably face and to select a relatively safe location for a field station. Above all, they were not to allow the life scientists to get themselves killed. The life scientists and Earth scientists presented the plans for their groups to the other participants of the two workshops. Once again, the participants went beyond the initial requirements for the project (described above). One group came wearing appropriate garb (including a pith helmet for one member of the group). Another group showed pictures of their prospective base. A third group chose animals based on recently-discovered fossils.

The second part of the jigsaw was only for participants in the Earth-science workshop. Each of these groups was composed of two members who had studied Paleozoic periods (different ones) during the first part of the jigsaw (the Prehistoric Zoo exercise), one from a group that had worked on a Mesozoic period, and one from a group that had studied a Cenozoic period. One group was assigned to search for and describe patterns in extinction over the last $545 \mathrm{Ma}$, another to find patterns in global climate, another in sea level, another in tectonic activity, and the last group in atmospheric composition (see Supplementary Material 5 for advice to guide the investigation). Each group then presented their findings to the other participants.

\section{Week 3: Anthropogenic Climate Change: Predictions vs. Evidence}

Much of week 3 was taken up by the design of unit plans, but the participants had been reading a text: Dire Predictions (Mann and Kump, 2009) as homework for the previous two weeks. The participants started the week by plotting data showing how carbon dioxide concentrations have increased for the last two decades (Richardson, 2013). The final content project was to list the environmental problems that people anticipate being caused by global warming (both in the book and in the news), to research one of them (per group), and to break down the information into two categories: 1 ) evidence of changes already observed, and 2) predictions of changes that are inferred to be happening or likely to happen based on scientific principles. The activity emphasized the last three essential principles of climate literacy (U.S. Global Change Research Program, 2009; Table 2). The participants were able to compile a fairly

R. Teed and S. Franco. 2014. Journal of Geoscience Education 62(4), 587-597. DOI: 10.5408/13-039.1 
long list of specific problems through class discussion (see Supplementary Material 6). Each group collected and described evidence for a different problem and explained the reasoning that allowed people to understand how those problems could be caused by global warming. The topics that the groups studied were hurricanes, methane production, glacial retreat, wildfire, and droughts.

During the workshop, several of the participants paraphrased the guiding principle from Climate Literacy (U.S. Global Change Research Program, 2009, p. 6): "Humans can take actions to reduce climate change and its impacts." However, there was not enough time to address the future of climate change using an inquiry approach, although the physical science workshop taking place across the hall spent over a week on item " $\mathrm{E}$ " of the guiding principle, dealing with energy efficiency and alternative energy.

\section{Unit-Plan Project}

During the summer workshop, each participant also developed lesson plans (generally whole units) to allow them to use their updated content knowledge and their recent experience with inquiry in their own classrooms during the following school year. Throughout the workshop, the participants practiced inquiry learning techniques, particularly jigsaw. During the first week, the participants became familiar with the CoRe form (Mulhall et al., 2003) which they used to pull together content objectives for a simple lesson plan to address their part of the weather/climate jigsaw.

During the second week, each participants chose a unit topic and completed a new CoRE form for the unit. Of the 14 lesson-plan units that were taught and assessed during the followup, 11 addressed topics from week 1: basic climate and weather mechanisms, seasons, and biomes (Table 3). All of the units extended beyond the basic demonstration used in week 1 . One lesson covered fossils using material collected from the field trip and planned expeditions back in time similar to the project for week 2 . The other two dealt with climate change over geologic and recent history, covered in week 2 and week 3, one using a Trends-in-Time scaffold like the one developed for this workshop. The popularity of week-1 topics for units indicates that the participants need more opportunities to design short lessons during the summer workshop that they can then build into units as they did in week 1 . So perhaps weeks 2 and 3 should include some mini-lesson design.

The participants finished written descriptions of the unit plan and ordered supplies to run it by the end of the third week. Some participants worked in teams, each writing a part of the lesson plan, but committing to run the whole unit, whether together or in separate classrooms. The written description was graded based on completeness. The unit had to contain a description of the lessons, assessments, and resource bibliographies used. The unit had to be centered around a finished CoRe framework and include a brief description of the participant's school and students, relevant elements from the Ohio standards (benchmarks from the 2002 standards, content statements for the 2011 standards), a content outline (similar to the one in Supplementary Material 1), and a pedagogical discussion addressing inquiry and the learning cycle. Finally, one of the assessments for the unit had to be a content test that the

R. Teed and S. Franco. 2014. Journal of Geoscience Education 62(4), 587-597. DOI: 10.5408/13-039.1 
participants would use as a pre- and post-test to assess the impact of the units on their own students.

\section{Follow-up Program}

The follow-up program extended over the 2011-2012 school year. During this time, the participants finished, taught, and tested the unit plans that they had developed during the workshop. Participants also returned to Wright State University for three short (half-day to fullday) workshops. In August 2011, they presented their unit plans to one another and critiqued each other's pre- and post-test questions, a form of basic validation. During this meeting, they also picked up the supplies that they had ordered for their units and made appointments with one of the master teachers who had helped teach the summer workshop to visit their classrooms at least twice. Between September 2011 and May 2012, the master teacher helped the participants teach their unit plans and administer their pre- and post-tests.

In October 2011, the participants had rock and mineral identification training, since many of them had expressed interest in this topic during the summer workshop. The instructor also reviewed the requirements for analyzing the pre- and post-test data from the unit plans for the summary that would be due in May. The participants were required to create a spreadsheet with the response to each test question from each student (numbered, not named), and calculate the pre-test average, post-test average, and normalized gain (Hake, 1998). The participants also had to write a reflection on their experience of teaching their lesson and an interpretation of the pre- and post-test results. Finally, in May 2012, the participants met to present their students' pre- and post-test results from their lesson plans and to report on what worked as expected and what did not. They turned in the papers and spreadsheets with their results.

\section{WORKSHOP RESULTS}

\section{Impact of Summer Workshop on Content Learning of Participants}

The first day of the summer workshop, participants took a pre-test to assess prior content knowledge. It consisted of 12 questions to be answered with a few sentences (Table 4) and asked the participants to use mechanistic (cause \& effect) explanations rather than technical terms whenever possible. The participants took the same test again on afternoon of the last day of the workshop, and the results of the post-workshop test were compared to the results from the first to estimate content-knowledge gain during the workshop.

The participant content-knowledge test used a short-answer format rather than multiple-choice so that partially correct answers could be scored as such. On a typical multiplechoice test, incomplete understanding requires students to make educated guesses, which appear to be either completely wrong or completely right after scoring. The short answer format provided a more accurate reflection of participant content knowledge.

The workshop content pre- and post-test questions were based on the content outline (Supplementary Material 1), four questions from each week of the course. The questions and most of the scoring rubric were written by Rebecca Teed and validated in the sense of being reviewed by the other two instructors of the workshop and by the external evaluator. There

R. Teed and S. Franco. 2014. Journal of Geoscience Education 62(4), 587-597. DOI: 10.5408/13-039.1 
was no opportunity to pilot-test the questions before the workshop. While the pre-test was being marked, the scoring rubric (Supplementary Material 7) was expanded to include several unanticipated partially-correct participant answers.

The average pre-test score was $38.1 \%$ and the average post-test score was $75.6 \%$. Every participant's total score increased (Fig. 2), and the class' total score on each question increased between the pre- and post-test (Fig. 3). It is statistically less likely for participants with higher pre-test scores to increase those scores on the post-test, because they have fewer pre-test questions to answer correctly (or more completely correctly) than participants with lower posttest scores. So score gains were normalized to account for head-room on the pre-test using the following formula from Hake, (1998):

$$
<\mathrm{g}>=\text { (post-test score - pretest score)/ (100\% - pre-test score). }
$$

The average normalized gain $<$ g $>$ was $63.8 \%$ for the workshop content pre- and post-test, which is higher than average compared to similar pre- and post-tests for the 13 ITQ workshops offered from 2006-2010 (Basista, pers. comm.).

Cronbach's alpha, a measure of consistency among responses to test items, is commonly used as a measure of reliability on tests (Cronbach, 1951). In this case, it is an estimate of whether a total score for answers to the various questions that make up the test measure the same composite idea, such as understanding of climate. The alpha for the pretest was $85 \%$ and for the post-test, it was $73 \%$, highly to moderately reliable in a research context (Murphy and Davidhofer, 2005), but the sample size (18 participants) is small enough that these alpha values must be treated as estimates.

There was a lot of variation among the participants with respect to prior knowledge, but some of the difficulty with questions like \#7 on the pre-test may have been due to the requirement of a mechanistic explanation. Many participants answered question \#7 ("Why do we expect climate to get warmer with increased levels of atmospheric carbon dioxide?") with " $\mathrm{CO}_{2}$ is a greenhouse gas," on the pre-test without explaining what a greenhouse gas is. In the workshop, the instructors and participants focused on cause-and-effect explanations for climate change, especially for classroom instruction. On the post-test, most participants gave at least a partial explanation of how $\mathrm{CO}_{2}$ warms the atmosphere.

Question 12 about why more politicians want to control $\mathrm{CO}_{2}$ rather than water vapor was intended to be difficult because it requires an understanding of feedbacks. Participants with less experience with systems thinking were not expected to develop such an understanding during the workshop, but those with strong backgrounds in fields like ecology were able to improve their answers to question 12 between the pre- and post-test.

Respondents who mentioned politics did not include a scientific explanation in their answers, and it appears that these were fallback responses. Scores for this question were highly correlated with scores on other questions.

\section{Impact of Unit Plans on Content Learning of K-12 Students during the Follow-up Program}

The participants included pre- and post-tests in their unit plans in order to assess their students' content-knowledge gains. The number of questions included in their tests ranged

R. Teed and S. Franco. 2014. Journal of Geoscience Education 62(4), 587-597. DOI: 10.5408/13-039.1 
from six to fifteen questions. The shorter tests were short-answer and graded on a continuous scale, with points for partially correct answers, whereas the longer tests were multiple-choice. During the August follow-up meeting, the participants gave presentations in which they briefly described their units and then reviewed each of their pre-test questions. The instructor and the other participants recommended edits to many of these questions. The edits were informative because some of the participants had done a similar follow-up program in life-science ITQ workshops in previous years and had experience with developing and administering pre- and post-tests.

During the follow-up program, the participants taught the units that they had developed, administering the pre-test at the start of the first class and the post-test at the end of the last class. The average normalized learning gain $\langle\mathrm{g}\rangle$ for the 476 grade $1-12$ students who participated in the fourteen units and were assessed was $56 \%$ (Table 3 ). Results were excluded from one class in which the students collaborated on the responses to the pre-test. The greatest gains were in a highly motivated class (high-performing middle-school students studying fossils and planning their own time-travel expeditions). The lowest gains were reported by a participant who used direct instruction rather than inquiry to address the content covered by several pre-/post-test questions. That participant described limited student participation in the inquiry activities. Students in a special-education classroom, where much of the time in every unit was spent on reading skills (that were not directly assessed in the preand post-test) showed an average normalized gain of $30 \%$.

\section{Impact on Attitude in Participants}

Participants provided feedback regarding the impact of the institute through two methods: an Ohio Board of Regents (OBR) pre-post survey and a Horizon Local Systemic Change (LSC) pre-post survey (Horizon, Inc., 2006). The OBR survey is provided by OBR for all Ohio ITQ recipients. Participants completed both surveys on the first day of the summer institute and during the final follow-up workshop approximately 12 months later $(n=15)$. There are no data regarding the reliability or validity of the OBR instrument.

The OBR survey includes several Likert-scale questions asking the participant to indicate the level of agreement, ranging from Strongly Agree (1) to Strongly Disagree (5). The statements are written in a manner that reflects strong teaching attitudes, beliefs and practices. The responses to the questions in \#12 (participants' attitudes, beliefs and degree of confidence) indicate that more participants strongly agreed with the positive statements about their preparedness and attitudes towards teaching at the end of the follow-up program (Table 5). The largest increases are indicated for teaching methods and assessment. At the end of the follow-up program, more participants felt strongly that they were knowledgeable and had more understanding of their content and pedagogy and that they were effective teachers.

The OBR survey also includes 7 paired statements representing a continuum of practice on which participants placed themselves. One such paired statement asked the participant to indicate how students generally work in the participant's classroom. The five-point continuum provided was Students generally work in groups cooperatively (1) to Students generally work independently (5). Topics covered in the paired statements included assessment practices,

R. Teed and S. Franco. 2014. Journal of Geoscience Education 62(4), 587-597. DOI: 10.5408/13-039.1 
motivation efforts, classroom interaction practices, instructional practices, and student roles. The paired-statements responses indicated movement in one pair regarding instructional activities in classrooms. The paired statement was: "Students generally learn concepts and processes using hands-on approaches." After the follow-up program, participants indicated that they had moved on the continuum to more hands-on approaches in their instruction. Responses to other OBR questions indicate participants had increased their level of involvement in sharing their teaching with colleagues and other professionals. At the end of the summer workshop and again at the end of the follow-up program, all participants indicated they would recommend the institute to their colleagues.

The LSC teacher questionnaires were initially developed in 2000 through an NSF-funded contract with Horizon Research Incorporated. The intent was to develop instrumentation to track systemic change in teachers' attitudes and perceptions regarding their mathematics and/or science content preparedness, pedagogical preparedness, classroom practices, and support of their school principals for math and science teaching. Expert reviews established the validity of the instrument. The questionnaire contains 29 questions, all of which have from four to 24 sub-questions. Respondents have a choice of five Likert-style choices of Strongly Disagree to Strongly Agree; or four Likert choices of Not Adequately Prepared to Very Well Prepared or four Likert choices of Not Important to Very important. The items on the questionnaire were combined into composite variables through factor analysis to provide more reliable estimates of teachers' preparedness and classroom practices (Germuth et al., 2003). The composites of interest for this study were attitudes towards teaching, pedagogical preparedness and principals' support. Germuth et al. (2003) used Cronbach's alpha to measure internal reliability estimates for these composites, and the values $(0.67-0.76, p .<0.05)$ are in the acceptable to moderate range (Murphy and Davidhofer, 2005).

A Wilcoxon Rank Sum test using total scores indicated significant gains in attitudes towards teaching, $W=-74, p=0.01$ (pre- $n=15$, post- $n=15$ ); in addition, the increase in pedagogical preparedness was significant, $W=-120, p=0.0007$ (pre- $n=15$, post- $n=15$ ). The Wilcoxon signed rank test is a nonparametric alternative to the two-sample t-test and is preferred when the population cannot be assumed to be normal. The sample for this ITQ project cannot be reasonably assumed to be normal. There was no significant change in principals' support. The LSC survey results are supported by the OBR survey results.

In an open ended request for program impact, one teacher wrote: "I am ten times the teacher I was before ITQ! Being 1-8 certified didn't mean I had the content to be effective up to 8 , just certified - now I have both. The best take aways were the actual hands-on activities to use in class - and an understanding of the how and why for each activity."

\section{DISCUSSION}

\section{Assessment Limitations}

It is not possible to compare the workshop's effect on participant content knowledge and attitudes to those of the continuing-education programs within local school districts as those programs either do not collect or do not release pre- and post-test results. Similarly, the

R. Teed and S. Franco. 2014. Journal of Geoscience Education 62(4), 587-597. DOI: 10.5408/13-039.1 
participants' students clearly increased in their knowledge of the topics covered in the units that the participants taught and assessed, but there is no control group data from classes taught by teachers who did not participate in the program or by those who dropped out. Even before the workshop and follow-up program, the participants may have been excellent and confident teachers and their lessons were probably fairly effective before. Many of them had participated in similar workshops in previous years.

The motivation of the participants was critical to the success of the workshop and the follow-up program. The teachers who completed the program devoted considerable effort outside of class by reading the textbook and designing lessons. The participants who dropped out of the summer program did not turn in homework or turned in unacceptable work. However, since they did not take the post-test or post-survey, there is no way to measure what effect the program would have had on them.

\section{Workshop Recommendations}

The topics of ITQ workshops change each offering to allow participants to return to study content and design curriculum appropriate to different standards each year. If there were funding for another Earth Science workshop, the next topic would be plate tectonics. However, some of the techniques, particularly the first part of the jigsaw in week 1, with a set of scaffolding questions (perhaps not as detailed as those in Supplementary Material 3), CoRe exercise (Mulhall et al., 2003), and mini-lesson could be adapted to the new content. Since many of the week-1 mini-lessons inspired the participants to create and design unit plans on those topics, the same format should probably be repeated in week 3 , using week-3 topics. The final content project, which required the participants to discuss the use of evidence and reasoning, could be used as the scaffold for any Earth-science topic. If the participants invested an afternoon of what would have been project time into a second set of mini-lessons, more of them might consider week-2 and week-3 topics for their unit plans.

One problem with working with high-needs districts was recruitment, another was retention. Teachers from Dayton City schools mentioned that they could participate in no-cost professional development programs that do not take time beyond their usual work hours. Of the eight participants from partner districts, four did not complete the program. Programs like ITQ require strong support from school and district administrators. The ITQ participant application required a principal's signature. But one of the participants who dropped out of the follow-up program did so because her principal forbade her not only to teach the lesson-plan unit she designed in the workshop but to teach any science at all. She was told to have her students practice math problems during the science period in order to improve their standardized test scores. The original partnership letter written by one of the school districts from which most of the drop-outs came made no specific commitment to require their teachers to finish the program. Similar workshop programs described in the literature, such as the Satellites, Weather and Climate Teacher Professional Development Program at the University of Vermont (Dupigny-Giroux et al., 2012), have also struggled to recruit enough participants despite having measured positive effects on the content knowledge and pedagogical preparedness of the teachers who were involved.

R. Teed and S. Franco. 2014. Journal of Geoscience Education 62(4), 587-597. DOI: 10.5408/13-039.1 


\section{CONCLUSION}

The 2011-2012 Earth science ITQ program for in-service teachers focused on climate change over geologic time. The participants engaged in jigsaw exercises to increase their content knowledge and developed multi-lesson unit plans that they taught in their own classrooms during the following year. The participants' pre- and post-test results indicate that the summer workshop increased teacher content knowledge. Their attitudes towards teaching and pedagogical preparedness significantly improved over the twelve-month period of the workshop and follow-up program. Though there were numerous influences that could have contributed to the changes documented here, several of the participants stated that the professional development experience was one of the dominant contributors.

\section{Acknowledgements:}

We would like to thank our colleagues: Beth Basista, Phyllis Frysinger, Stacey Hundley, Melissa Schen, Bev Stambaugh, James Tomlin, and the participants. Funding was provided by a grant from the Ohio Board of Regents - Improving Teacher Quality Program (\#10-48) and tuition scholarships from Wright State University. This manuscript was improved by the advice of Kristen St. John, Susan Buhr Sullivan, Jennifer Anderson, and an anonymous reviewer.

\section{SUPPLEMENTARY MATERIALS}

Supplementary Materials referred to above are available online at https://www.tandfonline.com/doi/suppl/10.5408/13-039.1.

\section{REFERENCES}

Basista, B., Mathews, S. 2002. Integrated Science and Mathematics Professional Development Programs. School Science and Mathematics. 102(7): 359-370.

Blakey, R. 2009. Triassic. Available at http://jan.ucc.nau.edu/ rcb7/230NAt.jpg (accessed 26 April, 2013).

Blakey, R. 2014. Colorado Plateau Geosystems, Inc. - Reconstructing the ancient Earth. Available at http://cpgeosystems.com/index.html (accessed 20 April, 2014).

Committee on Prospering in the Global Economy of the 21st Century: An Agenda for American Science and Technology, National Academy of Sciences, National Academy of Engineering, Institute of Medicine. 2007. Rising above the gathering storm: Energizing and employing America for a brighter economic future. Available at http://www.nap.edu/catalog/11463.html (accessed 18 Feb., 2012).

Cronbach, L. J. 1951. Coefficient alpha and the internal structure of tests. Psychometrika, 16(3), 297-334.

Dahl, J., Anderson, S.W., and Libarkin, J.C., 2005, Digging into Earth science: alternative conceptions held by K-12 teachers: Journal of Science Education, 6(2), p. 65-68.

Dupigny-Giroux, L.-A., Toolin, R., Hogan, S., and Fortney, M.D. 2012. The Satellites, Weather and Climate (SWAC) Teacher Professional Development Program: Making the case for climate and geospatial literacy. Journal of Geoscience Education 60(2), 133-146.

R. Teed and S. Franco. 2014. Journal of Geoscience Education 62(4), 587-597. DOI: 10.5408/13-039.1 
Germuth, A. A., Banilower, E. R., Shimkus, E. S. 2003. Test-retest reliability of the local systemic change teacher questionnaire. Retrieved from http://www.horizonresearch.com/LSC/news/tq_test_retest.pdf (accessed 24 April 2013).

Glen, W. 1994. How Science Works in the Mass-Extinction Debates. In Glen, W., eds, The massextinction debates: How science works in a crisis. Stanford, CA: Stanford University Press, p. 39-91.

Hake, R. R. (1998). Interactive-engagement versus traditional methods: A six-thousand student survey of mechanics test data for introductory physics courses. American Journal of Physics, 66(1), 64-74.

Horizon, Inc. (2006). Local Systemic Change through Teacher Enhancement Science 6-12 Teacher Questionnaire. Retrieved from http://www.horizonresearch.com/horizonresearchwp/wpcontent/uploads/2013/04/teacher_questionnaire_s6121.pdf (accessed 10 April 2014).

McComas, W.F., and H. Almazroa. 1998. The nature of science in science education: An introduction. Science \& Education 7:511-532.

Mulhall, P., Berry, A., and Loughren, J. 2003. Frameworks for representing science teachers' pedagogical content knowledge. Asia-Pacific Forum on Science Learning and Teaching 4(2), Article 2. Available at http://www.ied.edu.hk/apfslt/v4_issue2/mulhall/index.htm (accessed 15 Oct., 2012).

Mann, M.E., and Kump, L.E. 2009. Dire Predictions: Understand Global Warming. New York, NY: Pearson Education.

Murphy, K.R., and C.O. Davidshofer. 2005. Psychological testing: Principles and applications, $6^{\text {th }}$ Ed., Upper Saddle River NJ: Pearson Prentice Hall.

National Science Teachers Association. 2005. Project Earth Science: Meteorology, $2^{\text {nd }}$ Ed. Arlington, VA: NSTApress.

Ohio Department of Education. 2003. Academic Content Standards K-12 Science. Ohio Department of Education: Columbus, Ohio.

Ohio Department of Education. 2011a. Ohio revised science standards and model curriculum: Grades preK through eight. Available at http://education.ohio.gov/getattachment/Topics/Academic-ContentStandards/Science/Grades-K-8-Science_Model_Curriculum_October2013-1.docx.aspx (accessed 30 Jan. 2012).

Ohio Department of Education. 2011b. Ohio revised science standards and model curriculum:

High school. Available at http://education.ohio.gov/getattachment/Topics/Academic-ContentStandards/Science/HSscience_Model_Curriculum_October2013.docx.aspx (accessed 30 Jan. 2012).

Ohio Department of Education. 2011c. Ohio school report cards: Archives. Available at http://reportcard.education.ohio.gov/Pages/Archives.aspx (accessed 11 February 2013).

R. Teed and S. Franco. 2014. Journal of Geoscience Education 62(4), 587-597. DOI: 10.5408/13-039.1 
Richardson, R. 2013. Carbon dioxide exercise. Available at http://serc.carleton.edu/introgeo/interactive/examples/co2.html (accessed 29 April 2014).

Richmond, G. M., and Fullerton, D. S. (1986). Summation of Quaternary glaciations in the United States of America. Quaternary Science Reviews 5, 183-196.

Scotese, C. 2003. Paleomap Project. Available at http://www.scotese.com/ (accessed 29 April 2014).

Teed, R., and Wright, C. 2014. Personal timeline. Available at http://serc.carleton.edu/NAGTWorkshops/time/activities/61059.html (accessed 29 April 2014).

Trend, R. D. 2001. Deep time framework: A preliminary study of U.K. primary teachers' conceptions of geological time and perceptions of geoscience: Journal of Research in Science Teaching 38(2): 191-221.

University of California. 2014. University of California Museum of Paleontology. Available at http://www.ucmp.berkeley.edu/ (accessed 29 April 2014).

U.S. Global Change Research Program. 2009. Climate literacy: The essential principles of climatic sciences (2nd version). Available at http://www.globalchange.gov/browse/reports/climate-literacy-essential-principlesclimate-science-high-resolution-booklet (accessed 1 July 2014).

Wright, W.B. 1914. The Quaternary Ice Age. London: Macmillan and Co.

Wise, S.B. 2010. Climate change in the classroom: Patterns, motivations, and barriers to instruction among Colorado science teachers. Journal of Geoscience Education 58(5): 297-309.

Yoon, K.S., Duncan, T., Lee, S.W.-Y., Scarloss, B., Shapley, K.L. 2007. Reviewing the evidence on how teacher professional development affects student achievement. (Issues \& Answers Report, REL 2007-No. 033). Washington, DC: U.S. Department of Education, Institute of Education Sciences, National Center for Education Evaluation and Regional Assistance, Regional Educational Laboratory Southwest. Available at http://ies.ed.gov/ncee/edlabs (accessed 18 February 2013).

R. Teed and S. Franco. 2014. Journal of Geoscience Education 62(4), 587-597. DOI: 10.5408/13-039.1 
FIGURE 1: Map used for the Pangea project, modified from Blakey (2009). The information on the map legend, scale, and positions of rifts and trenches was communicated verbally in the 2011 workshop.

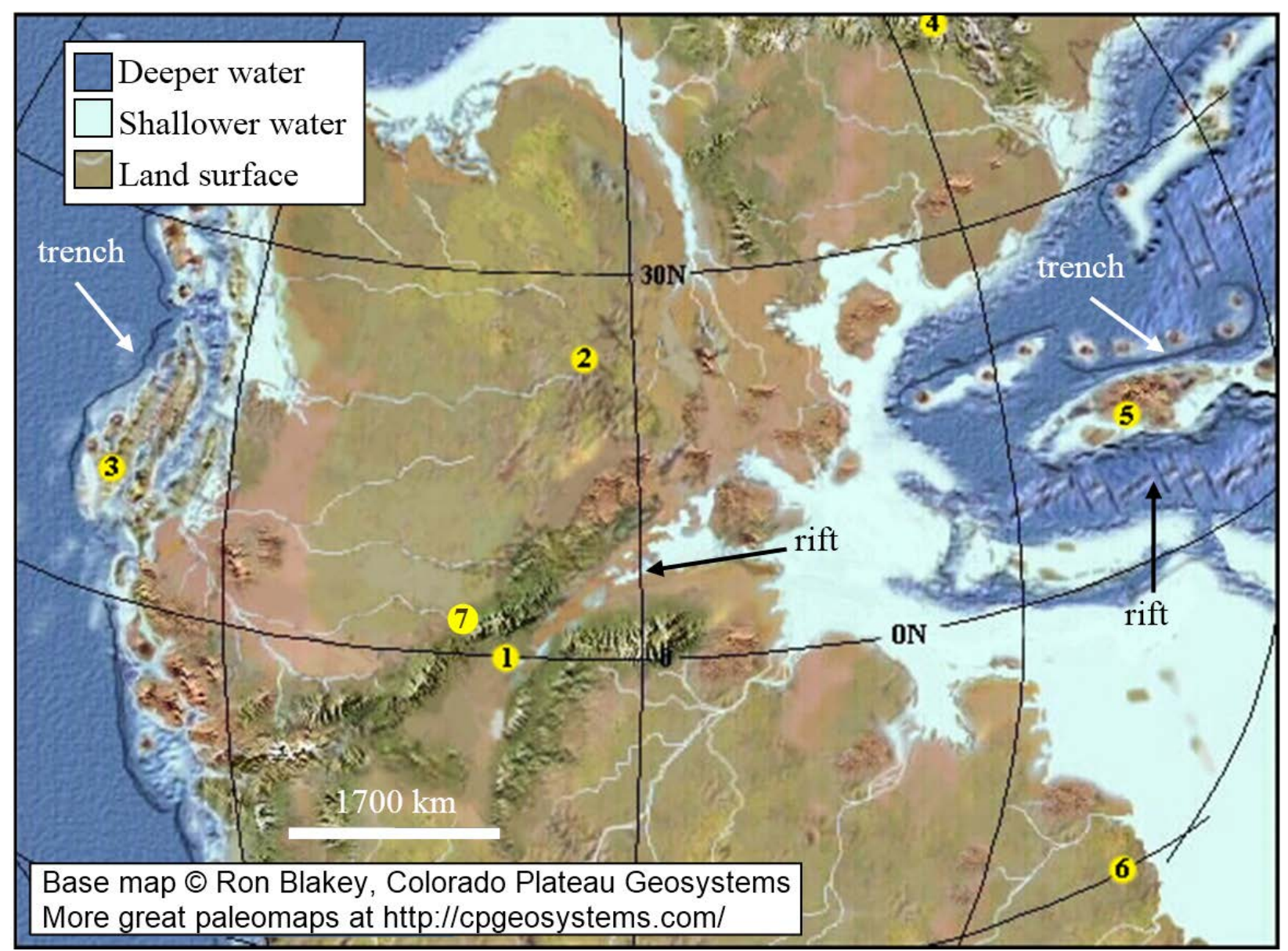

R. Teed and S. Franco. 2014. Journal of Geoscience Education 62(4), 587-597. DOI: 10.5408/13-039.1 
FIGURE 2: Participant content pre- \& post-test scores from the summer workshop

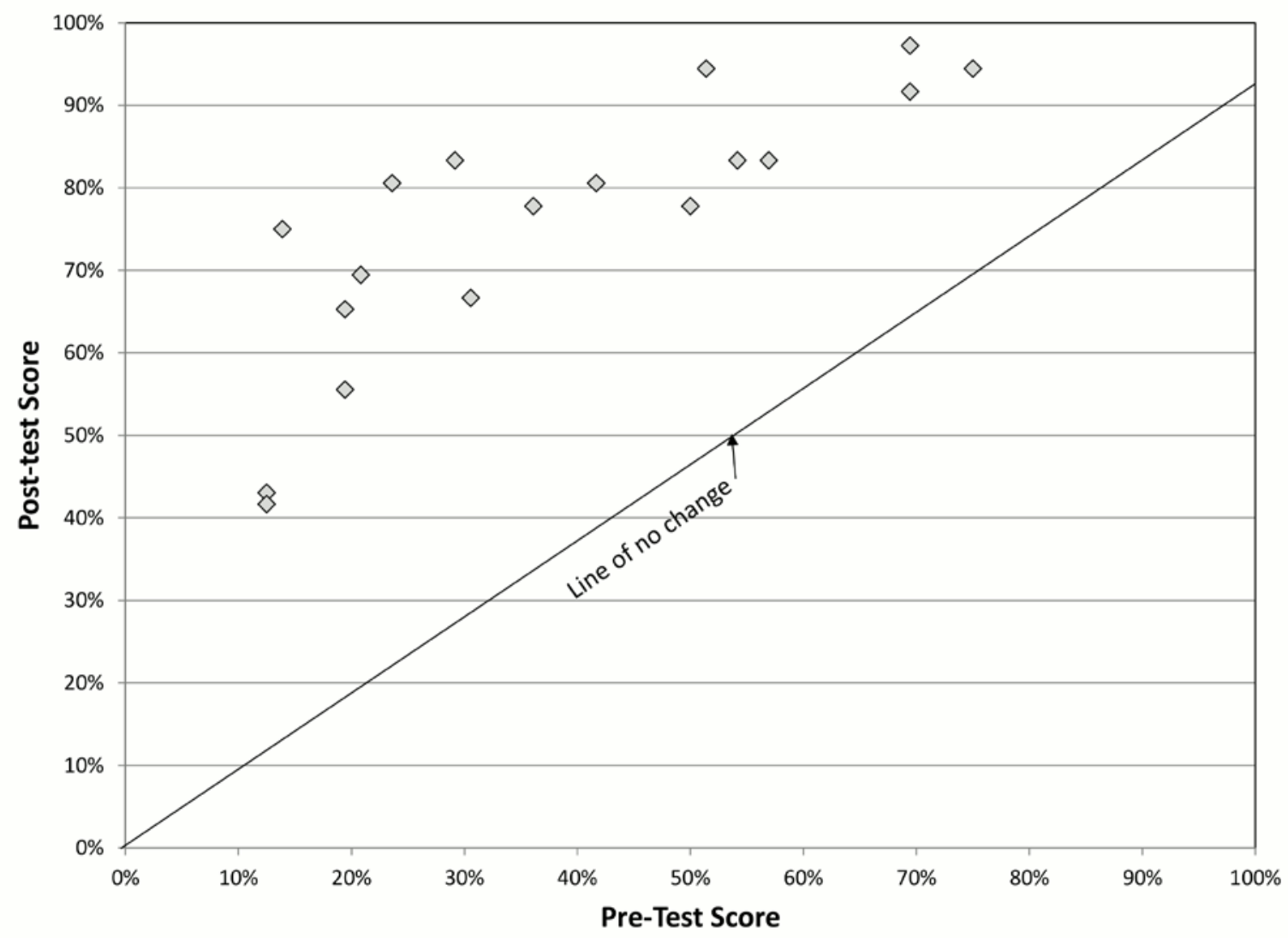


FIGURE 3: Scores on individual content pre- \& post-test questions from the summer workshop

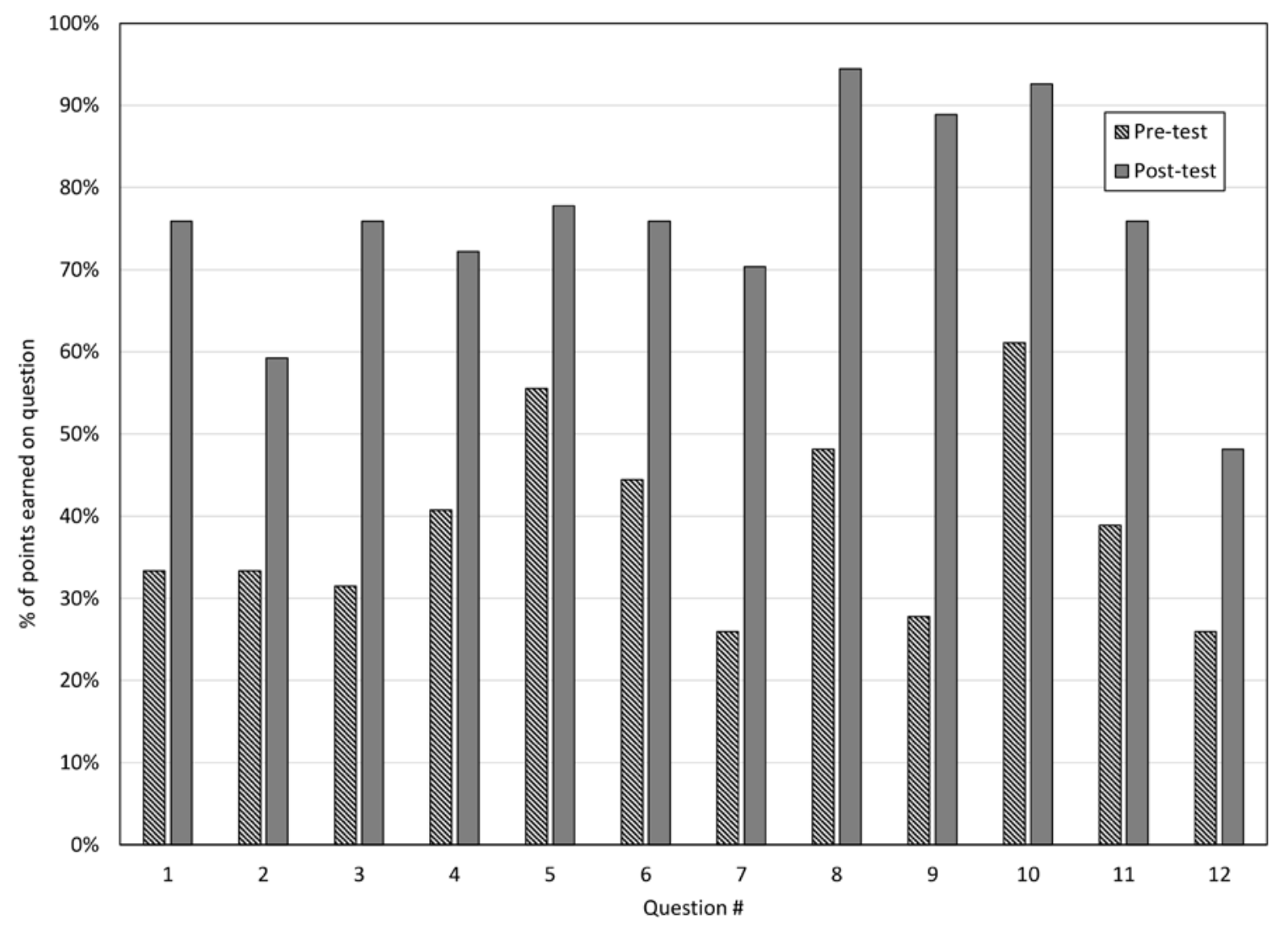

R. Teed and S. Franco. 2014. Journal of Geoscience Education 62(4), 587-597. DOI: 10.5408/13-039.1 
TABLE 1: Self-reported data on workshop participants and 2010-2011 Ohio Department of Education (2011c) school ratings.

\begin{tabular}{|c|c|c|c|c|c|}
\hline $\begin{array}{l}\text { Grades } \\
\text { Taught }\end{array}$ & Subjects Taught & Gender & Completion & School Rating & $\begin{array}{l}\text { Targeted } \\
\text { District? }\end{array}$ \\
\hline 1 & All & $\mathrm{F}$ & All & Academic Watch & Yes \\
\hline $1-8$ & Special Education & $\mathrm{F}$ & All & Academic Watch & Yes \\
\hline $3-5$ & Science & $\mathrm{F}$ & Summer & Academic Watch & Yes \\
\hline $4-5$ & Math \& Science & $\mathrm{F}$ & All & Academic Watch & Yes \\
\hline $4-6$ & Special Education & $\mathrm{F}$ & All & Academic Watch & Yes \\
\hline $4-8$ & Math, Social Studies & $\mathrm{F}$ & All & N/A (private) & No \\
\hline $5-6$ & Special Education & $\mathrm{F}$ & Week 1 & Not Rated ${ }^{2}$ & Yes \\
\hline 6 & Science \& Math & $F$ & All & $\begin{array}{l}\text { Excellent } \\
\text { w/Distinction }\end{array}$ & No \\
\hline $6-8$ & Science & $\mathrm{F}$ & All & Excellent & No \\
\hline $6-8$ & Science & $M$ & All & Excellent & No \\
\hline $6-8$ & Science & $\mathrm{F}$ & All & Excellent & No \\
\hline $6-8$ & Science & $\mathrm{F}$ & All & Excellent & No \\
\hline $6-8$ & Science & $\mathrm{F}$ & All & Excellent & No \\
\hline 7 & Science & $M$ & All & $\begin{array}{l}\text { Excellent } \\
\text { w/Distinction }\end{array}$ & No \\
\hline $7-8$ & Special Education & $\mathrm{F}$ & Week 1 & Effective & Yes \\
\hline $9-12$ & $\begin{array}{l}\text { Biology \& Physical } \\
\text { Science }\end{array}$ & $M$ & All & Excellent & No \\
\hline $9-12$ & Biology & $\mathrm{F}$ & All & Excellent & No \\
\hline $9-12$ & Science & $M$ & Summer & Effective & No \\
\hline 10 & Biology & $M$ & All & Excellent & No \\
\hline $11-12$ & Chemistry & $M$ & Summer & $\begin{array}{l}\text { Continuous } \\
\text { Improvement }\end{array}$ & Yes \\
\hline \multicolumn{6}{|c|}{$\begin{array}{l}{ }^{1} \text { Two high-need districts were given priority for recruitment and registration: Dayton City } \\
\text { and Trotwood. }\end{array}$} \\
\hline $\begin{array}{l}{ }^{2} \text { Too fe } \\
2006\end{array}$ & 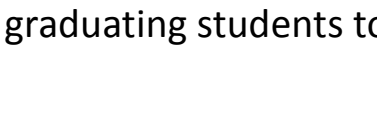 & & & & 05- \\
\hline
\end{tabular}

R. Teed and S. Franco. 2014. Journal of Geoscience Education 62(4), 587-597. DOI: 10.5408/13-039.1 
TABLE 2: Climate literacy principles addressed by the 2012 ITQ Earth Science Enhancement Workshop

\begin{tabular}{|l|c|l|l|}
\hline \multicolumn{2}{|l|}{} & \multicolumn{2}{l|}{ Primarily Addressed } \\
\hline Principle & Week & Project \\
\hline $\begin{array}{l}\text { 1) The sun is the primary source of energy for Earth's } \\
\text { climate system. }\end{array}$ & 1 & $\begin{array}{l}\text { Climate Mechanism Jigsaw } \\
\text { Pt. I }\end{array}$ \\
\hline $\begin{array}{l}\text { 2) Climate is regulated by complex interactions among } \\
\text { components of the Earth system. }\end{array}$ & 1 & $\begin{array}{l}\text { Climate Mechanism Jigsaw } \\
\text { Pt. I }\end{array}$ \\
\hline $\begin{array}{l}\text { 3) Life on Earth depends on, is shaped by, and affects } \\
\text { climate. }\end{array}$ & 1 \& 2 & $\begin{array}{l}\text { Climate Mechanism Jigsaw } \\
\text { Pt. I, Prehistoric Zoo }\end{array}$ \\
\hline $\begin{array}{l}\text { 4) Climate varies over space and time through both } \\
\text { natural and man-made processes. }\end{array}$ & 2 & $\begin{array}{l}\text { Prehistoric Zoo \& Trends } \\
\text { through Time }\end{array}$ \\
\hline $\begin{array}{l}\text { 5) Our understanding of the climate system is improved } \\
\text { through observations, theoretical studies, and } \\
\text { modeling. }\end{array}$ & 3 & Predictions vs. Evidence \\
\hline 6) Human activities are impacting the climate system. & 3 & Predictions vs. Evidence \\
\hline $\begin{array}{l}\text { 7) Climate change will have consequences for the Earth } \\
\text { system and human lives. }\end{array}$ & 3 & Predictions vs. Evidence \\
\hline
\end{tabular}


TABLE 3: Pre- and Post-test Results of Follow-up on Participants' K-12 Students. Overall values for $\langle\mathrm{g}\rangle$ were weighted by the number of students tested for each unit.

\begin{tabular}{|c|c|c|c|c|c|c|c|}
\hline Grade & District & Class & Topic & $\begin{array}{c}\# \\
\text { Students }\end{array}$ & $\begin{array}{c}\text { Mean } \\
\text { pre-test }\end{array}$ & $\begin{array}{c}\text { Mean } \\
\text { post-test }\end{array}$ & $\begin{array}{c}\text { Mean } \\
<\mathrm{g}>\end{array}$ \\
\hline 6 & $\begin{array}{c}\text { Bethlehem } \\
\text { Lutheran }\end{array}$ & Social Studies & Monsoons & 5 & $56 \%$ & $78 \%$ & $50 \%$ \\
\hline 7 & $\begin{array}{c}\text { Centerville } \\
\text { City }\end{array}$ & Science & Climate & 50 & $9 \%$ & $62 \%$ & $58 \%$ \\
\hline 7 & $\begin{array}{c}\text { Centerville } \\
\text { City }\end{array}$ & Science & Climate & 48 & $5 \%$ & $51 \%$ & $48 \%$ \\
\hline 7 & $\begin{array}{c}\text { Centerville } \\
\text { City }\end{array}$ & Science & Climate & 49 & $7 \%$ & $68 \%$ & $66 \%$ \\
\hline 7 & $\begin{array}{c}\text { Centerville } \\
\text { City }\end{array}$ & Science & Climate & 48 & $8 \%$ & $52 \%$ & $48 \%$ \\
\hline 7 & $\begin{array}{c}\text { Centerville } \\
\text { City }\end{array}$ & Science & Climate & 49 & $8 \%$ & $65 \%$ & $62 \%$ \\
\hline 1 & Dayton City & All Subjects & Seasons & 25 & $56 \%$ & $84 \%$ & $60 \%$ \\
\hline $7-8$ & Dayton City & Special Ed & Biomes & 17 & $23 \%$ & $46 \%$ & $30 \%$ \\
\hline 5 & Dayton City & Science & Seasons & 45 & $2 \%$ & $54 \%$ & $53 \%$ \\
\hline 6 & $\begin{array}{l}\text { Oakwood } \\
\text { City }\end{array}$ & Science & Fossils & 21 & $21 \%$ & $90 \%$ & $88 \%$ \\
\hline 7 & $\begin{array}{l}\text { Oakwood } \\
\text { City }\end{array}$ & Science & Climate & 40 & $7.1 \%$ & $50 \%$ & $46 \%$ \\
\hline $11-12$ & Troy City & Biology II & $\begin{array}{l}\text { Climate } \\
\text { Change }\end{array}$ & 40 & $40 \%$ & $83 \%$ & $72 \%$ \\
\hline 10 & $\begin{array}{l}\text { Vandalia- } \\
\text { Butler City }\end{array}$ & Biology & $\begin{array}{l}\text { Climate } \\
\text { Change }\end{array}$ & 20 & $43 \%$ & $52 \%$ & $16 \%$ \\
\hline 9 & $\begin{array}{l}\text { Yellow } \\
\text { Springs }\end{array}$ & $\begin{array}{c}\text { Earth/Space } \\
\text { Science }\end{array}$ & Biomes & 19 & $14 \%$ & $67 \%$ & $62 \%$ \\
\hline & Overall & 476 & & & $56 \%$ \\
\hline
\end{tabular}


TABLE 4: Content pre- and post-test questions for the Earth science summer workshop participants. The test form also included a space for the participant name and the instructions: "Use mechanistic (cause \& effect) explanations rather than technical terms whenever possible."

\begin{tabular}{|l|}
\hline 1) What kind of weather do you associate with low air pressure? \\
2) What is one major difference between the climate of Dayton OH and that of Minneapolis \\
3) Where are most of Earth's large deserts? Why? \\
\hline 4) What is an isobar, and why is it important? \\
\hline 5) What is the major cause of sea-level change over the last 500 million years? \\
\hline 6) What are two pieces of evidence for sea-level change from the rock record? \\
\hline $\begin{array}{l}\text { 7) Why do we expect climate to get warmer with increased levels of atmospheric carbon } \\
\text { dioxide? }\end{array}$ \\
\hline $\begin{array}{l}\text { 8) Name one ancient time period, and compare the global climate at that time with the } \\
\text { present. }\end{array}$ \\
\hline 9) What are two pieces of evidence for or against anthropogenic global warming? \\
\hline 10) What are two potentially serious effects of global warming? \\
\hline $\begin{array}{l}\text { 11) What is remarkable about the twentieth-century record of carbon-dioxide buildup } \\
\text { (recorded by the Keeling/Mauna Loa curve)? }\end{array}$ \\
\hline $\begin{array}{l}\text { 12) Water vapor is a more powerful greenhouse gas than carbon dioxide, and often more } \\
\text { plentiful. Why aren't any politicians focused on controlling it? }\end{array}$ \\
\hline
\end{tabular}


TABLE 5: Change in percentage of participants responding "strongly agree" on the Ohio Board of Regents pre- and post-survey.

\begin{tabular}{|l|c|c|}
\hline \multicolumn{1}{|c|}{ Statement } & \% Strongly agree \\
\hline \multicolumn{1}{|c|}{} & Pre- & Post- \\
\hline I have a good understanding of fundamental core content in my discipline. & $60 \%$ & $87 \%$ \\
\hline $\begin{array}{l}\text { I have a good understanding of relating classroom activities to Ohio's } \\
\text { Academic Standards }\end{array}$ & $40 \%$ & $73 \%$ \\
\hline $\begin{array}{l}\text { I have a good understanding of how to assess student learning in multiple } \\
\text { ways. }\end{array}$ & $20 \%$ & $73 \%$ \\
\hline $\begin{array}{l}\text { I have a good understanding of effective questioning techniques and its use } \\
\text { in the classroom. }\end{array}$ & $33 \%$ & $73 \%$ \\
\hline $\begin{array}{l}\text { I have a good understanding of how to use technology effectively in the } \\
\text { classroom. }\end{array}$ & $27 \%$ & $40 \%$ \\
\hline $\begin{array}{l}\text { I have a good understanding of the methods necessary to teach math } \\
\text { and/or science concepts effectively. }\end{array}$ & $33 \%$ & $87 \%$ \\
\hline I believe I am an effective teacher. & $47 \%$ & $73 \%$ \\
\hline I am excited about teaching in my subject area. & $80 \%$ & $87 \%$ \\
\hline I am interested in networking with teachers and other professionals. & $87 \%$ \\
\hline
\end{tabular}

